\title{
Investigation of the Self-efficacy of the Teachers in Technological Pedagogical Content Knowledge and Their Use of Information and Communication Technologies
}

\author{
Ömer Şimşek ${ }^{1, *}$ \& Firat Sarsar ${ }^{2}$ \\ ${ }^{1}$ Ziya Gökalp Faculty of Education, Dicle University, Diyarbakır, Turkey \\ ${ }^{2}$ Faculty of Education, Ege University, İzmir, Turkey \\ ${ }^{*}$ Correspondence: Department of Computer Education and Instructional Technologies, Ziya Gökalp Faculty of \\ Education, Dicle University, 21280, Diyarbakır, Turkey. E-mail: omarsimsek@gmail.com
}

Received: January 9, 2018

Accepted: February 6, 2019 Online Published: February 20, 2019

doi:10.5430/wje.v9n1p196

URL: https://doi.org/10.5430/wje.v9n1p196

\begin{abstract}
The aim of this study was to determine the teachers' views on technological pedagogical content knowledge (TPACK) self-efficacy and the frequency of using ICT in education and to examine whether there is a differentiation in these views according to certain variables. In addition, the relationship between teachers' use of ICT and TPACK-ISTE self-efficacy in various processes is examined. The study which is carried out with a descriptive survey, causal comparison and correlational survey models includes 387 secondary and high school teachers as study sample. In the study, teachers consider themselves very competent especially in terms of content knowledge. TPACK-ISTE self-efficacy of vocational and technical teachers was significantly higher than that of the science and mathematics teachers. While teachers benefit from ICT tools less frequently in measurement and evaluation as well as in presenting the course subject; in terms of presenting the course subject, high school teachers use ICTs significantly more often than the secondary school teachers; those who did receive in-service training on the use of technology in education use ICTs significantly more often than those who did not receive it. It is seen from the study results that the variables such as preparing the lecture notes, presenting the course subject and doing study explain the TPACK-ISTE self-efficacy significantly.
\end{abstract}

Keywords: educational technology, technology integration in education, technological pedagogical content knowledge, use of information and communication technologies

\section{Introduction}

With the development of internet and mobile technologies, the Information and Communication Technology (ICT) has become a more interactive structure. While access to information and the possibility to share information through ICT provide great innovations to many professional fields, it should also be organized according to the appropriate environments and activities that enable learning ICT abilities in the field of education. It is thought that teachers' effective use of these technologies in learning teaching process plays an important role in increasing the quality of education because many countries make hardware and software investments in technology to use in their educational systems. The achievement of such large-scale investments depends on the joint action of many components, particularly on the determination of the needs of teachers for effective technology integration skills in education. Recently, there have been challenges in the use of technology for educational purposes, despite the increased access to technology in the classroom (Voogt, Erstad, Dede, \& Mishra, 2013). Accordingly, the curricula should be structured so that they can use current technological tools and resources accurately and effectively (Yeh, Hsu, Wu, Hwang, \& Lin, 2014) and teachers who are the practitioners of the curricula should have the skills to integrate effective technology in education (Voogt \& Roblin, 2010).

For effective technology integration, the teacher should act as an instructional designer to plan the use of technology to support student learning, and the school environment should provide the technological opportunities to support this role of the teacher (Dexter, 2002). Within this context, it is highlighted that there is a dynamic relationship 
between the curriculum and technological opportunities. In order for teachers to become practitioner communities, it is suggested to identify and eliminate the factors preventing technology integration (Kopcha, 2010; Zhao \& Frank, 2003). The healthy implementation of this process depends on the existence and implementation of a professional development plan within the scope of nationally or internationally recognized qualifications for teachers. The technological pedagogical content knowledge (TPACK), which provides a framework for technology integration related competencies in education, can play an important role in determining a number of goals for teachers to achieve their technology integration skills in education (Baran, Chuang, \& Thompson, 2011). Within the framework of these competencies, it is stated that teachers' technology, pedagogy and content knowledge structures are integrated and that there is a dynamic relationship between these knowledge structures according to the old education technology perception focusing on technology (Mishra \& Koehler, 2005). The TPACK's framework provides guidance on what skills teachers can demonstrate for technology integration in education. This framework was called the technological pedagogical content knowledge by Koehler and Mishra, and it was developed by a number of design experiments (Abbitt, 2011a). They define the knowledge of how technology, pedagogy and content interact with each other so that teachers can make effective teaching in the field (Koehler \& Mishra, 2005; Mishra \& Koehler, 2005; Harris, Mishra, \& Koehler, 2007; Koehler \& Mishra, 2009). In order to determine the qualifications of teachers for effective technology integration in education, within the framework of TPACK, technology knowledge, pedagogy knowledge, content knowledge, technological content knowledge, technological pedagogy knowledge and technological pedagogical content knowledge are included. With these three dimensions (technological knowledge, pedagogical knowledge and content knowledge) of the interaction of the three basic knowledge structures in the context of the twenty-first-century competencies of teachers, they can provide important ideas in determining the level of teachers' ability to realize technology integration in education.

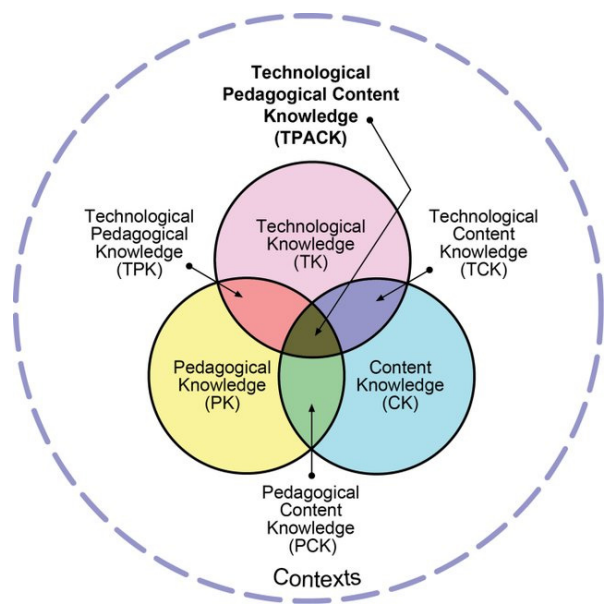

Figure 1. Components of TPACK Structure (Koehler and Mishra, 2008)

There are several competencies frameworks that address the twenty-first-century teacher traits in the context of technology integration in education, such as TPACK. In addition, ISTE's technology standards for teachers and pre-service teachers are a widely used framework for the use of technology in learning and teaching processes by universities, educational institutions and schools (Peck, Augustine, \& Popp, 2003). According to these standards, teachers should organize the classroom environment so that their students can use technology and so that they can use technology effectively (Seferoglu, 2009). These standards provide a very important roadmap, covering the features of technology integration, to succeed in the training of teachers in effective technology literacy (Bucci, Cherup, Cunningham, \& Petrosino, 2003). ISTE standards for teachers (ISTE, 2008):

1. Facilitate and inspire student learning and creativity,

2. Design and develop digital age learning experiences and assessments,

3. Model digital age work and learning

4. Promote and model digital citizenship and responsibility,

5. Engage in professional growth and leadership 
This study examines the TPACK-ISTE self-efficacy created according to the performance indicators of ISTE standards by considering the dimensions of the teachers within the scope of TPACK. TPACK-ISTE self-efficacy in the study is considered as the opinions of prospective teachers on the capacity to use effectively with technology (Wang, Ertmer, \& Newby, 2004). Self-efficacy is individuals' judgment on the capacity of organizing and performing the necessary activities to show a certain performance (Bandura, 1977). Teachers' belief about technology integration is an important component affecting teacher self-efficacy (Albion, 2001). The knowledge domains in the TPACK model have a significant and positive correlation with self-efficacy beliefs about technology integration (Abbit, 2011b; Lee \& Tsai, 2010). Therefore, it is important to reveal teachers' self-efficacy beliefs about TPACK (Lee \& Tsai, 2010; Aydın-Günbatar, Boz, \& Yerdelen-Damar, 2017).

Making comparisons in many dimensions of TPACK-ISTE self-efficacy according to the personal characteristics of teachers within the context of these dimensions may provide a point of view on the enablers or inhibitors of technology integration competencies in education. For example, as the structure of the curricula of the teachers in different school levels, the activities in the course processes and the developmental characteristics of the students they teach may vary, and the frequency of using TPACK self-efficacy and the use of ICT for educational purposes may vary. The teaching experience of teachers can be seen as an important factor in terms of being open to or resisting to innovation and may vary according to TPACK-ISTE self-efficacy. In-service training related to the use of technology in education in terms of teachers' professional development can be seen as important in teachers' integration of technology in education and also can be limited in terms of TPAB-ISTE self-efficacy. Within this context, effective technology integration in education may vary according to teachers' individual differences or experiences. Considering previous studies, these variables may have been studied in many respects. However, as already mentioned before, developments in technology in general and more specifically in ICTs require these variables need to be dealt with in new study frameworks. Although quantitative study reveals more superficial relationships and differentiation, these studies can be useful in identifying general trends and generating large-scale solutions.

This study was carried out with a broad teacher profile working in 21 different branches including gender; level of school teachers serves in, educational degree and teaching experience. Since the technological pedagogical content knowledge is based on ISTE's educational technology performance indicators, TPACK-ISTE self-efficacy is viewed as an important capacity perception in providing the technology integration in education according to the constructivist approach (Morphew, 2012). In addition to this, teachers' frequency of using ICT when doing study, using e-mail and social media, preparing the lecture notes, presenting the subject in the course, making measurement and evaluation at any stage of the course process, can provide an important point of view in terms of using technology for pedagogical purposes in education (Hennessy, Ruthven, \& Brindley, 2005).

\subsection{Aim of the Study}

The main aim of this study was to examine teachers' views on the competencies of technology integration in education in the context of TPACK-ISTE self-efficacy. For this purpose, their responses given for the technological pedagogical content knowledge model, which is one of the technology integration frameworks in education, and the technology knowledge, pedagogy knowledge, content knowledge, technological pedagogical knowledge, technological pedagogical content knowledge determined in the context of international educational technology standards for teachers (ISTE, 2008) are examined. In addition, in some cases, the frequency of ICT usage of teachers was examined and the relationship between TPACK-ISTE self-efficacy was determined. The answer to the following questions was sought according to the sub-objectives of the study.

1. What is the TPACK-ISTE self-efficacy level of teachers?

2. Does the teacher's TPACK-ISTE self-efficacy differ significantly according to the gender, the branch, the level of the school they serve in, the teaching experience, the education degree and the in-service training for the use of technology in education?

3. How often do teachers benefit from information and communication technologies (ICTs) when preparing lecture notes, presenting the subject in the course, measuring and evaluating, studying, using e-mail and social media?

4. Does the teachers' frequency of using ICT vary significantly according to their gender, branch, and level of school, teacher experience, education degree and in-service training? 
5. How and to what extent do the frequency of using ICT in preparing lecture notes, presenting the subject in the course, measurement and evaluation, doing study, communication (e-mail) and social media significantly explain TPACK-ISTE self-efficacy?

\section{Methods}

\subsection{Study Design}

The descriptive survey, causal comparison and correlational survey methods were used in the study. The descriptive survey design was used to determine how teachers' TPACK-ISTE self-efficacy scores were distributed in general mean and sub-dimensions, and to determine the frequency of ICT use in education. This design is a quantitative type of study conducted in order to describe the tendencies, attitudes or opinions of individuals in a sample selected from a universe by means of a data collection tool (Creswell, 2012). Causal comparison study is conducted to determine the causes or consequences of the differences between individuals or groups (Fraenkel, Wallen, \& Hyun, 2012). In such study, the causes and consequences of the differences between groups of people are determined without any intervention on the circumstances and participants (Büyüköztürk, Kılı̨̧ Çakmak, Akgün, Karadeniz, \& Demirel, 2008). In this study, according to the gender, branch of the school, the level of the school, the teaching experience, the education degree and the status of in-service training, TPACK-ISTE self-efficacy and ICT usage frequencies were examined using the causal comparison. Another sub-objective of this study is to evaluate to what extent the teachers' the frequency of using information and communication technologies (ICT) in preparing teachers' lecture notes, presenting the subject, measuring and evaluating, doing study, communication (e-mail) and using social media affects the TPACK-ISTE self-efficacy scores of the teachers. In order to determine this, predictive study design was used. Fraenkel, Wallen and Hyun (2012) stated that if such a study has sufficiently large relationship between two variables, the outcome variable can be predicted by the predictive variable.

\subsection{Participants}

A total of 387 secondary and high school teachers participated in the study. The data were collected from a total of 26 schools, including 15 secondary schools and 11 high schools with cluster sampling method. There is a total of 6970 secondary and high school teachers in the central districts of the provinces where the study was conducted. According to the sample calculation for the known universe, a minimum of 365 people should be reached in a universe of 6970 with a $5 \%$ error and a $95 \%$ confidence interval. According to this, in this study, it was observed that the sample $(\mathrm{n}=387)$ represents the universe.

Table 1. Demographic Characteristics of Participants

\begin{tabular}{lllll}
\hline Variable & Feature & f & $\%$ & Total (f) \\
\hline \multirow{2}{*}{ Gender } & Male & 244 & 63.0 & \multirow{2}{*}{ Teaching level } \\
& Female & 143 & 37.0 & \\
& Secondary school & 207 & 53.5 & 387 \\
& High school & 180 & 46.5 & \\
Science and mathematics & 127 & 32.8 & \\
& Vocational-technical areas & 31 & 8.0 & \multirow{2}{*}{386} \\
& Special ability areas & 36 & 9.3 & \\
Level of education & Verbal-Social areas & 138 & 35.7 & \\
& Foreign Language & 54 & 14.0 & \\
& Undergraduate Degree & 346 & 89.4 & 387 \\
& Graduate Degree & 41 & 10.6 & \\
Teaching experience & 1 year & 27 & 7.0 & \\
& 2-5 years & 47 & 12.1 & \\
& 6-10 years & 86 & 22.2 & 372 \\
& 11-15 years & 74 & 19.1 & \\
& 16-20 years & 63 & 16.3 & \\
\hline
\end{tabular}

*Science and mathematics: Physics, chemistry, biology and mathematics; Vocational technical fields: electricity, electronics, furniture technology, machine technology and metal technologies; Special ability areas: physical education, visual arts and music; Verbal-social areas: Turkish, Turkish language and literature, social studies, history, geography, philosophy and theology; and Foreign language: English and German 
According to Table 1, it was noted that most of the participants were male teachers $(63 \%)$ and the majority have bachelor's degree (89.4\%). It can be said that the participants are close to each other in terms of their teaching levels. Data were collected from 21 different branches. Branches were determined by integrating some of the teaching areas with each other. According to this, the proportion of teachers in the fields of science and mathematics, and in verbal and social areas accounted for more than half of the participants $(68.5 \%)$. In terms of teaching experience, teachers were evaluated in six groups. The teachers with the first year of teaching experience were addressed as a separate group. The other groups are divided into groups of experience, as referred to in the literature. The least participant group consisted of 1-year (7.0\%) and 2-5-year (12.1) teachers.

\subsection{Data Collection}

TPACK-ISTE self-efficacy scale developed by Şimsek and Yazar (2016) was used in this study. The scale includes Mishra and Koehler's (2006) model of technological pedagogical content knowledge and self-efficacy statements that include performance indicators based on the standards (2008) set by the International Educational Technology Association (ISTE) for teachers. This scale, which consists of six subscales, includes technological knowledge, pedagogy knowledge, content knowledge, pedagogical content knowledge, technological pedagogical knowledge and technological pedagogical content knowledge. The six items of the data collection instrument are related to personal information and the other six items are related to the frequency of using ICT in some processes. The remaining 27 statements consist of TPACK-ISTE self-efficacy scale. TPACK-ISTE self-efficacy scale, which is a five-point Likert scale, is as follows: "totally agree, agree, slightly agree, do not agree and totally disagree".

A total of 397 teachers participated in the study. However, after analyzing the outliers and residual values (Mahalanobis \& Cook), 10 participants were excluded from the analysis and data of 387 teachers were utilized.

\subsection{Data Analysis}

Since TPACK-ISTE self-efficacy scale was developed for pre-service teachers, confirmatory factor analysis (CFA) was performed to determine the construct validity of this scale. Considering the modification indexes $(\mathrm{m} 3$ and $\mathrm{m} 4)$ added to the CFA tested with 6 latent and 27 indicator variables, it was found that the Chi-square value was significant after the testing of the CFA model and the fit index values were acceptable or well-matched. $\left(\mathrm{X}^{2}=\right.$ 800.93, $\mathrm{n}=387, \mathrm{Sd}=308, \mathrm{p}<.001, \mathrm{RMSEA}=.064, \mathrm{SRMR}=0.047, \mathrm{NFI}=.97, \mathrm{NNFI}=.98, \mathrm{CFI}=.98, \mathrm{GFI}=.87$, AGFI $=.84)$. According to this, it can be said that other values except AGFI and GFI are close to a good fit or a good fit. Sümer (2000) stated that the GFI and AGFI values of the absolute fit indices are at .95 and above and that the ratio between .90-.95 shows satisfactory compliance. Anderson and Gerbing (1984); Cole (1987) Marsh, Balla and McDonald (1988) stated that if the GFI value is 0.85 and the AGFI value is over 0.80 , it can be considered acceptable for the fit (as cited in Büyüköztürk, Akgün, Demirel, \& Özkahveci, 2004).

The internal consistency of the TPACK-ISTE self-efficacy scale used in the study was examined with Cronbach's alpha coefficient. Accordingly, the Cronbach's alpha coefficients for the whole scale is as follows:95, TK.72, PK.84, CK.81, PCK.86, TPK.85 and TPACK .92. In the literature, the reliability coefficients of 70 and above are considered to be reliable (Nunnaly \& Bernstein, 1994; Pallant, 2007; Fraenkel, Wallen, \& Hyun, 2012).

In order to determine the distribution of TPACK-ISTE self-efficacy scores, arithmetic mean, standard deviation and coefficient of variation calculations were used. The mean scores of TPACK-ISTE self-efficacy scale were evaluated as follows: 1.00-1.80: Totally disagree, 1.81-2.60: Do not agree, 2.61-3.40: Slightly agree, 3.41-4.20: Agree and 4.21-5.00: Totally agree. Similarly, the frequency of information and communication technologies (ICT) in preparing teachers' lecture notes, presenting the subject, measuring and evaluating, using study, e-mail and social media were analyzed in the same way. ICT usage levels were evaluated as 1.00-1.80: Never, 1.81-2.60: Rarely, 2.61-3.40: Medium frequency, 3.41-4.20: Quite often and 4.21-5.00: Always. In addition, the coefficient of variation (V) was used to get an idea about the distribution of the responses. According to Güler (2011), the coefficient of variation (V) is a measure of dispersion that gives the percentage of the standard deviation to the arithmetic mean. If the distribution measure is $25<\mathrm{V}$, the scores are heterogeneous, in other words, they are different from each other and this shows that the difference between the scores is high. In this case, scores will show a more kurtosis distribution than normal. If the measure is between 20 and $25(20<\mathrm{V}<25)$, the scores show normal distribution. If the distribution measure is $\mathrm{V}<20$, the scores are homogeneous, in other words, they are similar, and the difference between the scores is not high. In this case, the scores will have a sharper distribution than normal.

To determine the statistical differences of TPACK-ISTE self-efficacy scores and ICT use frequencies according to various variables, normality for each variable was examined with Kolmogorov Smirnov. As a result, it was observed that the data were not normally distributed in all independent variables. According to this, the analyses 
were made by using Mann Whitney-U and Kruskal Wallis-H tests of the non-parametric tests. The significance level was .05 for determining differences. "r" values were used to determine the effect size of the significant difference in the study. The effect size is an indicator of the significance of study results in practice (Özsoy \& Özsoy). $r$ values for nonparametric tests were evaluated as follows: .10-.29 small, .30-.50 medium, .50 and above big effect (Cohen, 1988).

Regression analysis was performed to determine whether the variables predicted TPACK-ISTE scores. Sample size, missing data, normal distribution, linearity, residuals and outliers were examined before regression analysis. Outliers and Mahalanobis values, as well as Leverage and Cook distance values, were analyzed for regression analysis. Accordingly, 10 observations were excluded from the analysis. The KMO value was calculated as .96 for sample adequacy and it meets the criteria in the literature (Pallant, 2007; Tabachnick \& Fidell, 2007). In addition, Chi-square value $(\chi 2=6481.294, \mathrm{SD}=351, \mathrm{p}<.001)$ obtained using the Bartlett test was found to be significant. There are no missing data in the study. VIF and Tolerance values were investigated for multiple linear correlations. The highest Tolerance value is .842 and the lowest VIF value is 1.188 . Thus, it was observed that there were no multiple linear correlation problems. Standardized residual values for normality and linearity are examined. According to this, the Kolmogorov Smirnov normality test showed that the values were higher than $.05(.20)$ and that the residual values were linearly diagonal.

\section{Results}

The results of the study are presented as follows in relation to the study questions:

\subsection{Results Related to TPACK-ISTE Self-Efficacy of Teachers}

The mean scores, standard deviations and coefficient of variation obtained from TPACK-ISTE self-efficacy dimensions are shown in Table 2.

Table 2. TPACK-ISTE Self-Efficacy Levels of Teachers

\begin{tabular}{lllll}
\hline Dimensions & $\mathrm{n}$ & $M$ & $\mathrm{SD}$ & $\mathrm{V}$ \\
\hline TK & 387 & 3.93 & .64 & 0.16 \\
PK & 387 & 3.85 & .63 & 0.16 \\
CK & 387 & 4.23 & .62 & 0.15 \\
PCK & 387 & 4.01 & .59 & 0.15 \\
TPK & 387 & 3.93 & .72 & 0.18 \\
TPACK & 387 & 4.01 & .66 & 0.17 \\
General Mean & 387 & 3.99 & .54 & 0.13 \\
\hline
\end{tabular}

It can be observed from Table 2 that teachers' TPACK-ISTE self-efficacy scores are homogeneous and at the "agree" level in all dimensions except Content Knowledge (CK). It is noteworthy that teachers' CK -dimension self-efficacy levels are at the "totally agree" level. According to other dimensions, the lowest score is in Pedagogical Knowledge (PK). The TPACK-ISTE self-efficacy mean of teachers is at the "Agree" level.

\subsection{Comparison of TPACK-ISTE Self-Efficacy of Teachers According to Certain Variables}

In this sub-goal, whether there is a statistically significant difference between the mean scores of the sub-dimensions of TPACK-ISTE self-efficacy and the mean score of the scale, in general, were analyzed at the .05 significance level. The statistical differences and the effect size of these differences are indicated in Table 3.

Table 3. Mann-Whitney U Test Results of TPACK-ISTE Self-Efficacy Averages of Teachers

\begin{tabular}{|c|c|c|c|c|c|c|c|c|c|}
\hline Dimensions & Variable & Feature & $\mathrm{n}$ & $\begin{array}{l}\text { Mean } \\
\text { Rank }\end{array}$ & $\begin{array}{l}\text { Sum of } \\
\text { Ranks }\end{array}$ & $U$ & $\mathrm{z}$ & $\mathrm{p}$ & $r$ \\
\hline \multirow{2}{*}{ TK } & \multirow{2}{*}{ Gender } & Male & 244 & 202.51 & 49413.00 & 15369.00 & -1.97 & .040 & -.10 \\
\hline & & Female & 143 & 179.48 & 25665.00 & & & & \\
\hline \multirow{2}{*}{ TPACK } & \multirow{2}{*}{ Branch } & Vocational Technical & 31 & 103.08 & 3195.50 & 1237.50 & -3.21 & .001 & -.26 \\
\hline & & Science \& Mathematics & 127 & 73.74 & 9365.50 & & & & \\
\hline
\end{tabular}


According to Table 3, in terms of gender, only TK scores at the small effect level differed in favour of male teachers. $(U=15369.00, \mathrm{z}=-1.97, \mathrm{p}=.04, r=-.10)$. When the items in this dimension are examined one by one, it was seen that the responses given to the item "I can solve possible technological problems" differed in terms of gender. The mean scores of female teachers and male teachers are different for this item $(M=3.26, \mathrm{SS}=1.00)(M=3.57, \mathrm{SD}=.91)$. According to the significance level of .05 , it is significant in favor of males at small effect size $(U=14342.0 ; \mathrm{z}=-3.01$; $\mathrm{p}=.001 ; r=-0.16)$. According to the comparisons made with the Kruskal-Wallis $\mathrm{H}$ test in the branches of teachers, TPACK-ISTE scores showed a significant difference only in the TPACK dimension $\left(\chi^{2}(4)=10.437 ; \mathrm{p}=.03\right)$. According to the results of the Mann Whitney $U$ test, only the scores of teachers in the field of Science and Mathematics differed significantly at small effect size in favour of vocational-technical teachers $(U=1237.5 ; \mathrm{z}=$ $-3.21 ; \mathrm{p}=.001 ; r=-0.26)$.

No significant difference was found in the teachers' the TPACK-ISTE self-efficacy in the comparisons made according to the teachers receiving in-service training at the school they work in with regards to the teaching experience, the educational status and the use of technology in education.

Teachers who stated that they received in-service training for the use of technology in education $(n=241)$ considered the adequacy of in-service training given as part-sufficient. $(M=3.12, \mathrm{SD}=0.81, \mathrm{~V}=.26)$. However, the distribution of responses to this item is heterogeneous, that is, the views of the teachers receiving in-service training differentiate.

When the in-service training of the teachers in terms of the use of technology in education was examined, it was observed that more than half of the teachers in the secondary school did not receive this training $(55.6 \%)$, while the majority of the teachers in high school $(82.8 \%)$ received this training.

\subsection{Examining the Status of Teachers in Utilizing Information and Communication Technologies}

Table 4 shows the information on ICT utilization of the teachers in the processes such as preparing the lecture notes, presenting the subject in the course, measuring and evaluating, doing study, communication (e-mail) and social media.

Table 4. Teachers' Utilization of Information and Communication Technologies in Some Processes

\begin{tabular}{lllll}
\hline Processes & $\mathrm{n}$ & $M$ & $\mathrm{Sd}$ & $\mathrm{V}$ \\
\hline Preparing lecture notes & 387 & 3.61 & 1.06 & 0.29 \\
Presenting the subject in the course & 387 & 3.27 & 1.14 & 0.35 \\
Measurement and evaluation & 387 & 3.18 & 1.13 & 0.35 \\
Doing study & 387 & 3.89 & .99 & 0.25 \\
Communication(E-mail) & 387 & 3.68 & 1.16 & 0.32 \\
Social media (Facebook, Twitter, etc.) & 387 & 3.33 & 1.36 & 0.41 \\
General mean & 387 & 3.61 & 1.06 & 0.29 \\
\hline
\end{tabular}

According to Table 4, it is seen that the mean of ICT usage frequencies in the processes such as assessment and evaluation of teachers, presentation of the subject and social media (Facebook, Twitter) are at the "slightly agree" level. The mean of ICT usage frequencies in study, e-mail and preparation of lecture notes is at the "agree" level. It can be said that the distribution of responses to all dimensions is heterogeneous and the opinions varied.

\subsection{Comparison of Frequency of the Teacher's Use of ICTs According to Some Variables}

Table 5 shows the significant differences in ICT usage in terms of gender, branch, experience, level and level of education.

When Table 5 was examined, it was observed that the teachers in Vocational and Technical field have significantly more frequent ICTs use than the ones in science and mathematics and special ability teaching in preparing the lecture notes and presenting the subject in the course. It was determined that high school teachers use ICTs more frequently than secondary school teachers and those who received in-service training use ICT more compared to those who did not. Based on gender, it is seen that male teachers use ICT more frequently than female teachers when they do study and use communication (e-mail). In addition, it was found that teachers at graduate degree level used the ICT more frequently when doing study and using communication (e-mail) compared to the teachers at the bachelor's degree level. 
Table 5. Mann-Whitney-U Test Results of the Teachers Use the Frequency of Information and Communication Technologies in some Processes

\begin{tabular}{|c|c|c|c|c|c|c|c|c|c|}
\hline & Variable & Attribute & $\mathrm{n}$ & $\begin{array}{l}\text { Mean } \\
\text { Rank }\end{array}$ & $\begin{array}{l}\text { Sum of } \\
\text { Ranks }\end{array}$ & $U$ & $\mathrm{z}$ & $\mathrm{p}$ & $r$ \\
\hline \multirow{4}{*}{$\begin{array}{l}\text { Preparing lecture } \\
\text { notes }\end{array}$} & \multirow{4}{*}{ Branch } & Vocational Technical & 31 & 98.82 & 3063.50 & 1369.50 & -2.74 & .01 & -0.22 \\
\hline & & $\begin{array}{l}\text { Science and } \\
\text { mathematics }\end{array}$ & 127 & 74.78 & 9497.50 & & & & \\
\hline & & Vocational Technical & 31 & 40.94 & 1269.00 & 343.00 & -2.85 & .01 & -0.35 \\
\hline & & Special ability & 36 & 28.03 & 1009.00 & & & & \\
\hline \multirow{12}{*}{$\begin{array}{l}\text { Presenting the } \\
\text { subject in the } \\
\text { course }\end{array}$} & \multirow{2}{*}{ Level } & Secondary school & 207 & 176.78 & 36593.00 & 15065.00 & -3.36 & .01 & -0.17 \\
\hline & & High school & 180 & 213.81 & 38485.00 & & & & \\
\hline & \multirow{3}{*}{$\begin{array}{l}\text { In-service } \\
\text { training }\end{array}$} & Yes & 241 & 203.49 & 49040.50 & 15306.50 & -2.22 & .03 & -0.11 \\
\hline & & No & 146 & 178.34 & 26037.50 & & & & \\
\hline & & Vocational Technical & 31 & 104.15 & 3228.50 & 1204.50 & -3.48 & .01 & -0.28 \\
\hline & \multirow{7}{*}{ Branch } & $\begin{array}{l}\text { Science and } \\
\text { mathematics }\end{array}$ & 127 & 73.48 & 9332.50 & & & & \\
\hline & & Vocational Technical & 31 & 43.71 & 1355.00 & 257.00 & -3.93 & .01 & -0.48 \\
\hline & & Special ability & 36 & 25.64 & 923.00 & & & & \\
\hline & & Vocational Technical & 31 & 116.32 & 3606.00 & 1168.00 & -4.06 & .01 & -0.31 \\
\hline & & Verbal Social & 138 & 77.96 & 10759.00 & & & & \\
\hline & & Vocational Technical & 31 & 53.98 & 1673.50 & 496.50 & -3.22 & .01 & -0.35 \\
\hline & & Foreign Language & 54 & 36.69 & 1981.50 & & & & \\
\hline \multirow{4}{*}{ Doing study } & \multirow{2}{*}{ Gender } & Male & 244 & 182.15 & 44444.00 & 14554.00 & -2.86 & .01 & -0.15 \\
\hline & & Female & 143 & 214.22 & 30634.00 & & & & \\
\hline & Level of & Graduate Degree & 41 & 236.22 & 9685.00 & 5362.00 & -2.68 & .01 & -0.14 \\
\hline & Education & Undergraduate Degree & 346 & 189.00 & 65393.00 & & & & \\
\hline \multirow{4}{*}{$\begin{array}{l}\text { Communication } \\
\text { (e-mail) }\end{array}$} & \multirow{2}{*}{ Gender } & Male & 244 & 204.16 & 49814.50 & 14967.50 & -2.42 & .02 & -0.12 \\
\hline & & Female & 143 & 176.67 & 25263.50 & & & & \\
\hline & \multirow{2}{*}{$\begin{array}{l}\text { Level of } \\
\text { education }\end{array}$} & Graduate Degree & 41 & 244.20 & 10012.00 & 5035.00 & -3.15 & .00 & -0.16 \\
\hline & & Undergraduate Degree & 346 & 188.05 & 65066.00 & & & & \\
\hline
\end{tabular}

\subsection{Results Related to the Use of ICT Utilization Frequencies for Teachers' TPACK-ISTE Self-Efficacy}

Table 6. General Regression Results of ICT Utilization Frequencies and TPACK-ISTE Self-Efficacy Relationship

\begin{tabular}{|c|c|c|c|c|c|c|c|c|c|c|}
\hline Dimensions & $\mathrm{F}$ & $\mathrm{R}$ & $\mathrm{R}^{2}$ & $\mathrm{p}$ & 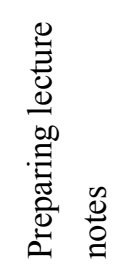 & 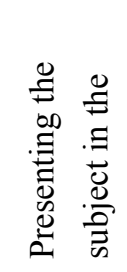 & 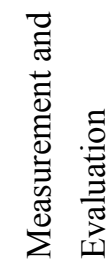 & 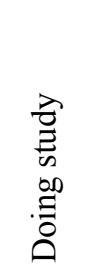 & 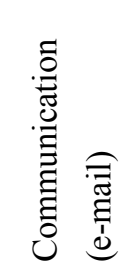 & $\begin{array}{l}\frac{\pi}{\pi} \\
\sum^{0} \\
. \frac{\pi}{0} \\
0 \\
\mathscr{0}\end{array}$ \\
\hline TK & 18.09 & .47 & .22 & .001 & $.004 *$ & $.003 *$ & .940 & .330 & $.003 *$ & .298 \\
\hline PK & 16.40 & .45 & .21 & .001 & $.003 *$ & $.001 * *$ & .530 & .201 & .637 & .482 \\
\hline $\mathrm{CK}$ & 6.63 & .31 & .10 & .001 & $.005^{*}$ & .182 & .149 & $.041^{*}$ & .738 & .593 \\
\hline PCK & 11.70 & .40 & .16 & .001 & $.043^{*}$ & $.025^{*}$ & .300 & .092 & .214 & .281 \\
\hline TPK & 16.27 & .45 & .20 & .001 & $.003 *$ & $.004 *$ & .691 & $.018^{*}$ & .225 & .496 \\
\hline TPACK & 20.54 & .50 & .23 & .001 & $.005^{*}$ & $.001 * *$ & .837 & $.010^{*}$ & .193 & .326 \\
\hline General Mean & 23.13 & .52 & .27 & .001 & $.001 * *$ & $.001 * *$ & .747 & $.019 *$ & .106 & .271 \\
\hline
\end{tabular}

$* \mathrm{p}<.05 ; * * \mathrm{p}<.001$ 
In this study, it was investigated whether the use of the TPACK-ISTE self-efficacy of the ICT was significantly observed in some processes.

According to Table 6, it is seen that variables such as preparing the lecture notes, presenting the subject and doing study explain the TPACK-ISTE self-efficacy significantly. All variables explain the maximum TPACK-ISTE self-efficacy. $\left(R^{2}=27, \mathrm{p}=.001\right)$, according to this, predictor variables explain $27 \%$ of TPACK-ISTE self-efficacy. When the other TPACK-ISTE self-efficacy dimensions were examined, it was detected that the ICT variables explain content knowledge dimension at a minimum level. Especially benefiting from ICT in preparing lecture notes and presenting the subject in the course explained all TPACK-ISTE dimensions significantly. The use of ICT in measurement evaluation and the use of social media did not significantly explain the TPACK-ISTE self-efficacy.

\section{Discussion and Conclusion}

In this study, three important aspects of technology integration in education were taken into consideration. TPACK, ICT and ISTE standards were the focus of this study and numerous variables regarding TPACK-ISTE self-efficacy and teachers' use of ICT were investigated. Teachers are required to meet some competencies in order to provide effective technology integration to classroom activities in terms of twenty-first-century skills (Clark, 2010; Canbazoglu Bilici et al., 2013). TPACK-ISTE self-efficacy includes valid and reliable performance indicators in meeting these skills at an international level (Şimşek \& Yazar, 2016). In this study, it was observed that teachers' TPACK-ISTE self-efficacy was high. Self-efficacy, which includes teachers' beliefs about their capacity to realize technology integration in education (Bandura, 1997), is an important factor in knowing and implementing TPACK (Lai \& Lin, 2018) and it can be stated that the participants are at least aware of the knowledge structures of this model.

While TPACK-ISTE self-efficacy of teachers was found high in the study, no significant difference was found between the TPACK-ISTE self-efficacy in the comparisons made according to the in-service training of the school where they work, their teaching experiences, educational level and the use of technology in education. In fact, the general expectation in the study was that the young teachers were expected to have a higher level of integration self-efficacy in education. On the other hand, it was noted that there is no statistically significant difference in these variables because the teachers participating in the study perceive themselves as competent in terms of TPACK-ISTE self-efficacy. However, it is considered that high TPACK-ISTE self-efficacy perception should be further investigated.

Moreover, male teachers' self-efficacy in technology knowledge is higher than female teachers. Male teachers perceive themselves better than female teachers especially in solving technological problems. There are past studies indicating that male teachers are less worried than female teachers while using computers (Busch, 1995). Furthermore, there are studies showing similar results in favour of males in terms of technology knowledge (Sweeney \& Drummond, 2012). Scherer and Siddiq (2015) argued that there is clearly gender discrimination in technology-related self-efficacy.

TPACK-ISTE self-efficacy of vocational and technical teachers in the study is significantly higher than in science and mathematics. Accordingly, teachers in different disciplines may have different self-efficacy for technology integration in education. ICT competences may vary with their culture related to various disciplines (Karaseva Siibak \& Pruulmann-Vengerfeldt, 2015). This situation may result from the structure and functioning of the disciplines (Darby, 2009).

The striking result in the study is that the majority of secondary school teachers did not receive in-service training on the use of technology in education, and the teachers in the high school level received more training in this regard. However, the teachers who received this training reported that general training is not sufficient. However, the TPACK-ISTE self-efficacy of the teachers teaching at a secondary or high school level did not differ.

According to another result of the study, teachers benefit from ICT tools less in measuring and evaluation. Similarly, in their study, Şimşek and Yazar (2017) reported that they used the ICT tools less often in the measurement and evaluation processes. In fact, there are very important areas for using ICT tools in a constructivist form for measurement and evaluation purposes and this issue is becoming more and more important. (Cayton-Hodges, Marquez, Keehner et al., 2012.)

In the study, it was seen that teachers in vocational and technical fields made more frequent use of ICT in preparing the lecture notes and presenting the subject in the course than in science and mathematics and special ability teaching. Thus, it can be said that teachers in vocational and technical fields found ICT technologies more related to their 
courses. According to the nature of the courses, the differentiation of ICT usage tendencies in the course processes of the teachers in different fields should be examined in terms of both TPACK and ICT usage frequency.

In terms of presenting the subject, high school teachers use ICTs more frequently than the secondary school teachers and those who received in-service training use ICTs more frequently than those who did not. This situation can be explained by the fact that FATIH project implemented in our country mainly provides hardware infrastructure. In other words, secondary schools had smart boards and internet technologies later than high schools. Therefore, the frequency of using ICTs may be higher. In addition, it can be seen that in-service training of Vocational development may be related to their frequency of ICT use. Of course, TPACK-ISTE self-efficacy did not differ significantly in terms of these variables. The differentiation in their ICT usage frequencies supports the fact that TPACK has a different information structure (Angeli \& Valanides, 2009).

In the study, it was observed that male teachers benefit more from ICT in study and communication (e-mail) compared to female teachers. In addition, teachers with a graduate level of education use ICT significantly more frequently during their study and communication (e-mail) than the teachers with only a bachelor's degree.

The results of the study explain the TPACK-ISTE self-efficacy of the variables, such as preparing the lecture notes, presenting the subject and doing study. In addition, teachers with a graduate level of education use ICT in study and communication (e-mail) significantly more frequently than those with only bachelor's degree. Scherer, Siddiq and Teo (2015) stated that there is a positive relationship between self-efficacy and use of ICT.

When the other TPACK-ISTE self-efficacy dimensions were examined, it was noted that the ICT variables indicate the minimum content knowledge dimension. In fact, in the study, teachers perceive themselves very well in terms of their content knowledge compared to other TPACK dimensions. This situation differs in terms of pedagogy knowledge and technology knowledge. Especially the use of ICT in the preparation of the lecture notes and the presentation of the subject in the course explain all the TPACK-ISTE dimensions significantly, while the use of ICT and the use of social media in measurement evaluation do not significantly explain TPACK-ISTE self-efficacy. In TPACK-ISTE self-efficacy, performance indicators of international education technology competencies are included. These performance indicators suggest that social media and measurement evaluation should be used in a student-centred manner (ISTE, 2008). In addition, teachers' use of ICT in the context of TPACK-ISTE was not found related to these matters at all. It can be inferred from that result that either the two variables are not related to directly TPACK or teachers do not use social media or do not use ICT in measurement and evaluation activities in education.

In conclusion, gender discrimination in technology-related issues is still going on in this study as well. Also, it is a crucial result that TPACK self-efficacy can be investigated especially in point of different curriculums. In addition, the use of ICT in measurement evaluation and the use of social media should be investigated in further studies.

\section{References}

Abbitt, J. T. (2011a). Measuring technological pedagogical content knowledge in preservice teacher education: A review of current methods and instruments. Journal of Study on Technology in Education, 43(4), 281-300. https://doi.org/10.1080/15391523.2011.10782573

Abbitt, J. T. (2011b). An investigation of the relationship between self-efficacy beliefs about technology integration and technological pedagogical content knowledge (TPACK) among preservice teachers. Journal of Digital Learning in Teacher Education, 27(4), 134-143. https://doi.org/10.1080/21532974.2011.10784670

Albion, P. R. (2001). Some factors in the development of self-efficacy beliefs for computer use among teacher education students. Journal of Technology and Teacher Education, 9(3), 321-347.

Angeli, C., \& Valanides N. (2009). Epistemological and methodological issues for the conceptualization, development, and assessment of ICT-TPCK: Advances in technological pedagogical content knowledge (TPCK). Computers \& Education, 52(1), 154-168. https://doi.org/10.1016/j.compedu.2008.07.006

Aydın-Günbatar, S., Boz, Y., \& Yerdelen-Damar, S. (2017). A closer examination of TPACK-self-efficacy construct: Modeling elementary pre-service science teachers' TPACK-self efficacy. Elementary Education Online, 16(3), 917-934. https://dx.doi.org/10.17051/ilkonline.2017.330232

Bandura, A. (1977). Self-efficacy toward a unifying theory of behavioural change. Psychological Review, 84(2), 191-215.

Bandura, A. (1997). Self-efficacy: The exercise of control. New York: W. H. Freeman and Company. 
Baran, E., Chuang, Hsueh-Hua \& Thompson, A. (2011). TPACK: An emerging study and development tool for teacher educators. The Turkish Online Journal of Educational Technology, 10(4), 370-377.

Bucci, T. T., Cherup, S., Cunningham, A., \& Petrosino, A. J. (2003). ISTE standards in teacher education: A collection of practical examples. The Teacher Educator, 39(2), 95-114. https://doi.org/10.1080/08878730309555333

Busch, T. (1995). Gender differences in self-efficacy and attitudes toward computers. Journal of Educational Computing Study, 12, 147-158. https://doi.org/10.2190/H7E1-XMM7-GU9B-3HWR

Büyüköztürk, Ş., Akgün, Ö. E., Demirel, F., \& Özkahveci, Ö. (2004). Güdülenme ve öğrenme stratejileri ölçeği’nin Türkçe formunun geçerlik ve güvenirlik çalışması. Kuram ve Uygulamada Eğitim Bilimleri Dergisi, 4(2), 207-239.

Büyüköztürk, Ş., Kılıç Çakmak, E., Akgün, Ö. E., Karadeniz, Ş., \& Demirel, F. (2008). Bilimsel araştırma yöntemleri. Ankara: Pegem Akademi.

Canbazoğlu Bilici, S., Yamak, H., Kavak, N., \& Guzey, S. S. (2013). Technological pedagogical content knowledge self-efficacy scale (TPACK-SeS) for preservice science teachers: Construction, validation and reliability. Eurasian Journal of Educational Study, 52, 37-60.

Cayton-Hodges, G. A., Marquez, E., Keehner, M., Laitusis, C., van Rijn, P., Zapata-Rivera, D., Bauer, M. I., \& Hakkinen, M. T. (2012). Technology Enhanced Assessments in Mathematics and Beyond: Strengths, Challenges, and Future Directions. Proceedings of the Invitational Study Symposium on Technology Enhanced Assessments.

Clark, J. (2010). The digital imperative: Making the case for a 21st-century pedagogy. Computers \& Composition, 27, 27-35. https://doi.org/10.1016/j.compcom.2009.12.004

Cohen, J. (1988). Statistical power analysis for the behavioural sciences (2nd ed.). Hillsdale, NJ: Erlbaum.

Creswell, J. W. (2012). Educational study: Planning, conducting, and evaluating quantitative. Prentice Hall.

Darby, L. (2009). Translating a "Relevance Imperative" into junior secondary mathematics and science pedagogy. Eurasia Journal of Mathematics, Science and Technology Education, 5(3), 277-288. https://doi.org/10.12973/ejmste/75279

Dexter, S. (2002). ETIPS: Educational technology integration and implementation principles. In P. Rogers (Ed.), Designing instruction for technology-enhanced learning (pp. 56-70). Hershey, PA: Idea Group Publishing.

Fraenkel, J. R., Wallen, N. E., \& Hyun, H. H. (2012). How to design and evaluate study in education (8th ed.). New York: McGraw Hill.

Güler, N. (2011). Eğitimde ölçme ve değerlendirme. Ankara: Pegem Akademi.

Harris, J. B., Mishra, P., \& Koehler, M. J. (2007). Teachers' technological pedagogical content knowledge: Curriculum-based technology integration reframed. Paper presented at the 2007 Annual Meeting of the American Educational Study Association, Chicago, IL.

Hennessy, S., Ruthven, K., \& Brindley, S. (2005). Teacher perspectives on integrating ICT into subject teaching: commitment, constraints, caution, and change. Journal of curriculum studies, 37(2), 155-192. https://doi.org/10.1080/0022027032000276961

International Society for Technology in Education (2008). ISTE Standards Teachers. Retrieved 05.02.2017 from http://www.iste.org/docs/pdfs/20-14_ISTE_Standards-T_PDF.pdf

Karaseva, A., Siibak, A., \& Pruulmann-Vengerfeldt, P. (2015). Relationships between teachers` pedagogical beliefs, subject cultures, and meditation practices of students' use of digital technology. Cyberpsychology: Journal of Psychosocial Study on Cyberspace, 9(1), article 6. http://dx.doi.org/10.5817/CP2015-1-6

Koehler, M. J., \& Mishra, P. (2005). What happens when teachers design educational technology? The development of technological pedagogical content knowledge. Journal of Educational Computing Study, 32(2), 131-152. https://doi.org/10.2190/0EW7-01WB-BKHL-QDYV

Koehler, M. J., \& Mishra, P. (2008). Introducing TPCK. In J. A. Colbert, K. E. Boyd, K. A. Clark, S. Guan, J. B. Harris, M. A. Kelly \& A. D. Thompson (Eds.), Handbook of technological pedagogical content knowledge for educators. (pp. 1-29). New York: Routledge. 
Koehler, M. J., \& Mishra, P. (2009). What is technological pedagogical content knowledge? Contemporary Issues in Technology and Teacher Education, 9(1), 60-70.

Kopcha, T. J. (2010). A systems-based approach to technology integration using mentoring and communities of practice. Educational Technology Study and Development, 58(2), 175-190. https://doi.org/10.1007/s11423-008-9095-4

Lai, T., \& Lin, H. (2018). An investigation of the relationship of beliefs, values and technological pedagogical content knowledge among teachers. Technology, Pedagogy and Education, 27(4), 445-458. https://doi.org/10.1080/1475939X.2018.1496137

Lee, M., \& Tsai, C. (2010). Exploring teachers' perceived self-efficacy and technological pedagogical content knowledge with respect to educational use of the world wide web. Instructional Science: An International Journal of the Learning Sciences, 38(1), 1-21. https://doi.org/10.1007/s11251-008-9075-4

Mishra, P., \& Koehler, M. (2005). Educational technology by design: Results from a survey assessing its effectiveness. In C. Crawford, C. Roger, I. Gibson, K. McFerrin, J. Price, R. Weber \& D. A. Willis (Eds.), Proceedings of the Society for Information Technology \& Teacher Education International Conference 2005 (pp. 1-7). Chesapeake, VA: AACE.

Mishra, P., \& Koehler, M. J. (2006). Technological pedagogical content knowledge: A framework for teacher knowledge. Teachers College Record, 108, 1017-1054. https://doi.org/10.1111/j.1467-9620.2006.00684.x

Morphew, V. N. (2012). A constructivist approach to the National Educational Technology Standards for teachers. International Society for Technology in Education: Eugene, Oregon - Washington, DC.

Nunnaly, J. C., \& Bernstein, I. H. (1994). Psychometric theory (3rd ed.). McGraw Hill.

Özsoy, S., \& Özsoy, G. (2013). Effect size reporting in educational study. Elementary Education Online, 12(2), 334-346.

Pallant, J. (2007). SPSS Survival Manual: A step by step guide to data analysis using SPSS for windows (3rd ed.). Maidenhead, England: Open University Press and McGraw Hill Education.

Peck, K. L., Augustine, C., \& Popp, D. (2003). The AECT project: Modeling the effective use of technology in teacher preparation. TechTrends, 47(2), 21-23. https://doi.org/10.1007/BF02763420

Scherer, R., Siddiq, F., \& Teo, T. (2015). Becoming more specific: Measuring and modelling teachers' perceived usefulness of ICT in the context of teaching and learning. Computers \& Education, 88, 202-214. https://doi.org/10.1016/j.compedu.2015.05.005

Seferoğlu, S. S. (2009). Yeterlikler, standartlar ve bilişim teknolojilerindeki gelişmeler ışığında öğretmenlerin sürekli mesleki eğitimi. Eğitimde Yansımalar IX: Türkiye'nin Öğretmen Yetiştirme Çıkmazı Ulusal Sempozyumu, ss. 204-217. Başkent Üniversitesi Eğitim Fakültesi ve Tekışık Eğitim Araştırma Geliştirme Vakfı, 12-13 Kasım 2009, Başkent Üniversitesi Bağlıca Kampüsü, ANKARA

Şimşek, Ö., \& Yazar, T. (2017). Investigation of teachers' educational technology standards self-efficacy. Pegem Journal of Education and Instruction, 7(1), 23-54. https://doi.org/10.14527/pegegog.2017.002

Şimşek, Ö., \& Yazar, T. (2016). Validity and reliability study of technological pedagogical content knowledge self-efficacy scale based on international educational technology standards (TPACK-ISTE). In O. Titrek \& M. Potmesil (Eds.), Proceedings book, 1st International Conference on Lifelong Learning and Leadership for All, Vol. 1. (pp. 259-268). 29-31 October 2015 - Palacky University \& Moravian University College Olomouc Olomouc, Czech Republic.

Sweeney, T. A., \& Drummond, A. (2012). How prepared are our pre-service teachers to integrate technology? A pilot study. Australian Computers in Education Conference ACEC12, Perth.

Tabachnick, B. G., \& Fidell, L. S. (2007). Using multivariate statistics (5th ed.). Boston: Pearson Education.

Voogt, J., \& Roblin, N. P. (2010). 21st-century skills discussion paper. Netherlands: Universiteit Twente.

Voogt, J., Erstad, O., Dede, C., \& Mishra, P. (2013). Challenges to learning and schooling in the digitally networked world of the 21st century. Journal of Computer Assisted Learning, 29(5), 403-413. https://doi.org/10.1111/jcal.12029

Wang, L., Ertmer, P. A., \& Newby, T. J. (2004). Increasing preservice teachers' self-efficacy beliefs for technology integration. Journal of Study on Technology in Education, 36(3), 231. 
https://doi.org/10.1080/15391523.2004.10782414

Yeh, Y. F., Hsu, Y. S., Wu, H. K., Hwang, F. K., \& Lin, T. C. (2014). Developing and validating technological pedagogical content knowledge-practical (TPACK-practical) through the Delphi survey technique. British Journal of Educational Technology, 45(4), 707-722. https://doi.org/10.1111/bjet.12078

Zhao, Y., \& Frank, K. A. (2003). Factors affecting technology use in schools: An ecological perspective. American Educational Study Journal, 40(4), 807-840. https://doi.org/10.3102/00028312040004807 